\title{
Percutaneous needle aponeurotomy for the treatment of Dupuytren's contracture
}

\author{
Dupuytren kontraktürü tedavisi için perkütan iğne aponörotomi
}

\author{
Mustafa Karakaplan, MD (D), Kadir Ertem, MD (D), Hacı Polat, MD (D), \\ Mehmet Şah Sakçı, MD (i), Yunus Oklu, MD (D)
}

Department of Orthopedics and Traumatology, Turgut Özal Medical Center, İnönü University Medical School, Malatya, Turkey

\begin{abstract}
Objectives: This study aims to present the early-period outcomes of patients with Dupuytren's contracture (DC) treated with percutaneous needle aponeurotomy technique.

Patients and methods: This retrospective study included 28 patients (20 males, 8 females; mean age 63 years; range, 44 to 88 years) (75 fingers) treated with percutaneous aponeurotomy due to DC between November 2011 and December 2015. Patients were evaluated according to their demographic characteristics, presence of additional disease, family history, history of drug use, complication rate, recurrence development, postoperative patient satisfaction, reoperational request, postoperative Disability of Arm Shoulder and Hand Questionnaire and visual analog scale scores.
\end{abstract}

Results: Mean follow-up duration was 29 months (range, 12 to 60 months). In the postoperative satisfaction questionnaire, $92.9 \% \quad(n=26)$ of patients stated that they were satisfied. In the questionnaire of reoperation request, $82.1 \%(n=23)$ of patients accepted the reoperation. While the complication rate was $39.3 \%$, recurrence rate was $35.7 \%$.

Conclusion: Percutaneous needle aponeurotomy technique may be an effective, simple, and safe method for the treatment of DC.

Keywords: Complications, Dupuytren's contracture, percutaneous aponeurotomy, reoperation.

Dupuytren's contracture (DC) is a progressive condition in which connective cords form, thicken, and shorten, typically in the connective tissue of the palmar fascia, causing permanent flexion
$\ddot{O Z Z}$

Amaç: Bu çalışmada perkütan iğne aponörotomi tekniği ile tedavi edilen Dupuytren kontraktürü (DK) olan hastaların erken dönem sonuçları sunuldu.

Hastalar ve yöntemler: Bu retrospektif çalışmaya Kasım 2011 ve Aralık 2015 tarihleri arasında DK nedeniyle perkütan aponörotomi ile tedavi edilen 28 hasta (20 erkek, 8 kadın; ort. yaş 63 yıl; dağılım, 44-88 yıl) (75 parmak) dahil edildi. Hastalar demografik özellikleri, ek hastalık varlığı, aile öyküsü, ilaç kullanım öyküsü, komplikasyon oranı, nüks gelişimi, ameliyat sonrası hasta memnuniyeti, yeniden ameliyat olma isteği, ameliyat sonrası Kol Omuz ve El Sorunları Anketi ve görsel analog ölçeği skorlarına göre değerlendirildi.

Bulgular: Ortalama takip süresi 29 ay (dağ 1 lım, 12-60 ay) idi. Ameliyat sonrası memnuniyet anketinde hastaların \%92.9'u (n=26) memnun kaldığını ifade etti. Yeniden ameliyat olma isteği anketinde hastaların \%82.1'i $(n=23)$ yeniden ameliyatı kabul etti. Komplikasyon oranı \%39.3 iken nüks oranı $\% 35.7$ idi.

Sonuç: Perkütan iğne aponörotomi tekniği DK tedavisi için etkili, basit ve güvenli bir yöntem olabilir.

Anahtar sözcükler: Komplikasyonlar, Dupuytren kontraktürü, perkütan aponörotomi, yeniden ameliyat olma.

contractures of joints and of one or more fingers. The metacarpophalangeal (MCP) joint and the proximal interphalangeal (PIP) joint are most often affected. Eventually, the contractures lead to hand deformity, 
impaired hand function, and potentially reduced quality of life for the affected individual. ${ }^{[1]}$ Many different approaches for the treatment of symptomatic contractures have been described. Conservative treatment options include physical therapy and rehabilitation, radiotherapy, steroid injection, 5 -fluorouracil injection, and oral tamoxifen use..$^{[2-6]}$ Surgical treatment methods include percutaneous needle aponeurotomy (PNA), open fasciotomy, partial fasciectomy (PF), radical fasciectomy, and dermofasciectomy. ${ }^{[7-11]}$ Complete fasciectomy is the most invasive intervention with the highest rate of complications, but has consistently lower recurrence rates. ${ }^{[9-11]}$ Recent years have shown a shift in interest towards less invasive treatment alternatives. In 1972, French rheumatologists Lermusiaux and Debeyre reintroduced the fasciotomy and performed it using a fine (25-gauge [G]) needle under local anesthesia, calling it percutaneous needle fasciotomy (PNF). Mainly Foucher and some hand surgeons have adopted this technique and favorable results have been reported. ${ }^{[7,12]}$ In recent years, collagenase injection has emerged as a popular treatment method. ${ }^{[13]}$ Injectable collagenase recently became available and has shown promise as a nonoperative approach. While recent studies show that injectable collagenase results in adequate correction for MCP joint contractures, its effectiveness at the PIP joints is less successful, particularly in patients with more severe contractures. ${ }^{[13-15]}$ The percutaneous approach has the benefit of rapid recovery, quick return to work, minimal healing time, and infrequent need for formal occupational therapy. In this study, we aimed to present the early-period outcomes of patients with DC treated with PNA technique. ${ }^{[16]}$

\section{PATIENTS AND METHODS}

We identified all patients treated with PNA as the primary mode of treatment for DC from surgical database of İnönü University Medical Faculty between November 2011 and December 2015. This was a consecutive series of patients operated on by a single surgeon. Patients who had undergone prior surgical release in the affected digits were excluded. The study included 28 patients ( 20 males, 8 females; mean age 63 years; range, 44 to 88 years) (75 fingers). Data on patient demographics, severity of disease, number of digits involved, preoperative contracture measurements, dominant hand involvement, additional illness, family history, drug use history, early/late complications, recurrence development, and time to recurrence were identified from medical records, operative reports, and outpatient charts. An independent observer, who was not directly involved in the care of the patients, recorded the patient satisfaction, reoperational request, the visual analog scale (VAS) pain, and Disability of Arm Shoulder and Hand (DASH) questionnaire scores at each followup visit. Patients were classified clinically in three grades. Grade 1 disease presents as a thickened nodule and a band in the palmar aponeurosis; this band may progress to skin tethering, puckering, or pitting. Grade 2 presents as a peritendinous band, and extension of the affected finger is limited. Grade 3 presents as flexion contracture. ${ }^{[17]}$ The study protocol was approved by the İnönü University Medical Faculty Ethics Committee. A written informed consent was obtained from each patient. The study was conducted in accordance with the principles of the Declaration of Helsinki.

We performed PNA in the operating room, under local anesthesia without using tourniquet or sedation. The patient rested supine with arm abducted on a hand table. The extremities to be treated were prepared with antiseptic solution. The fingers to be aponeurotomized were marked with a surgical pen (Figure 1). Local anesthesia was achieved by superficial injection of the skin directly overlying the Dupuytren's cords with $2 \%$ prilocaine hydrochloride (Priloc-Vem İlaç Sanayi, Tekirdağ, Turkey) using a $2 \mathrm{~mL}$ syringe and a 26G needle. The injections were carefully placed at an intra-dermal or very superficial subdermal level in order to anesthetize the skin only and to avoid anesthetizing the digital nerves. We did not use corticosteroids for any patients. The presence of intact distal sensation in the pulp of each digit was assessed prior to aponeurotomy to ensure that digital nerve function remained intact. We carefully chose portal site between skin creases in areas of definite cords. Skin creases were not used for portals because of the proximity of the flexor sheath and likelihood of skin tear. Portals were usually spaced a minimum of $5 \mathrm{~mm}$ wide. We used a 26G needle as a scalpel for aponeurotomy. Following the palpation of the cord and the nodules, the needle was inserted in a perpendicular position to the cord. The fingers were flexed and extended to ensure that the needle did not contact the flexor tendons. During the procedure, patients were warned to report any paresthesia in the fingers to avoid nerve damage. Fingertip sensitivity was repeatedly checked through the procedure. Releases were begun at distal portals, progressed proximally. Despite careful technique, anesthetic diffusion or mild nerve contusion may produce digital nerve conduction block. If sensitivity to 

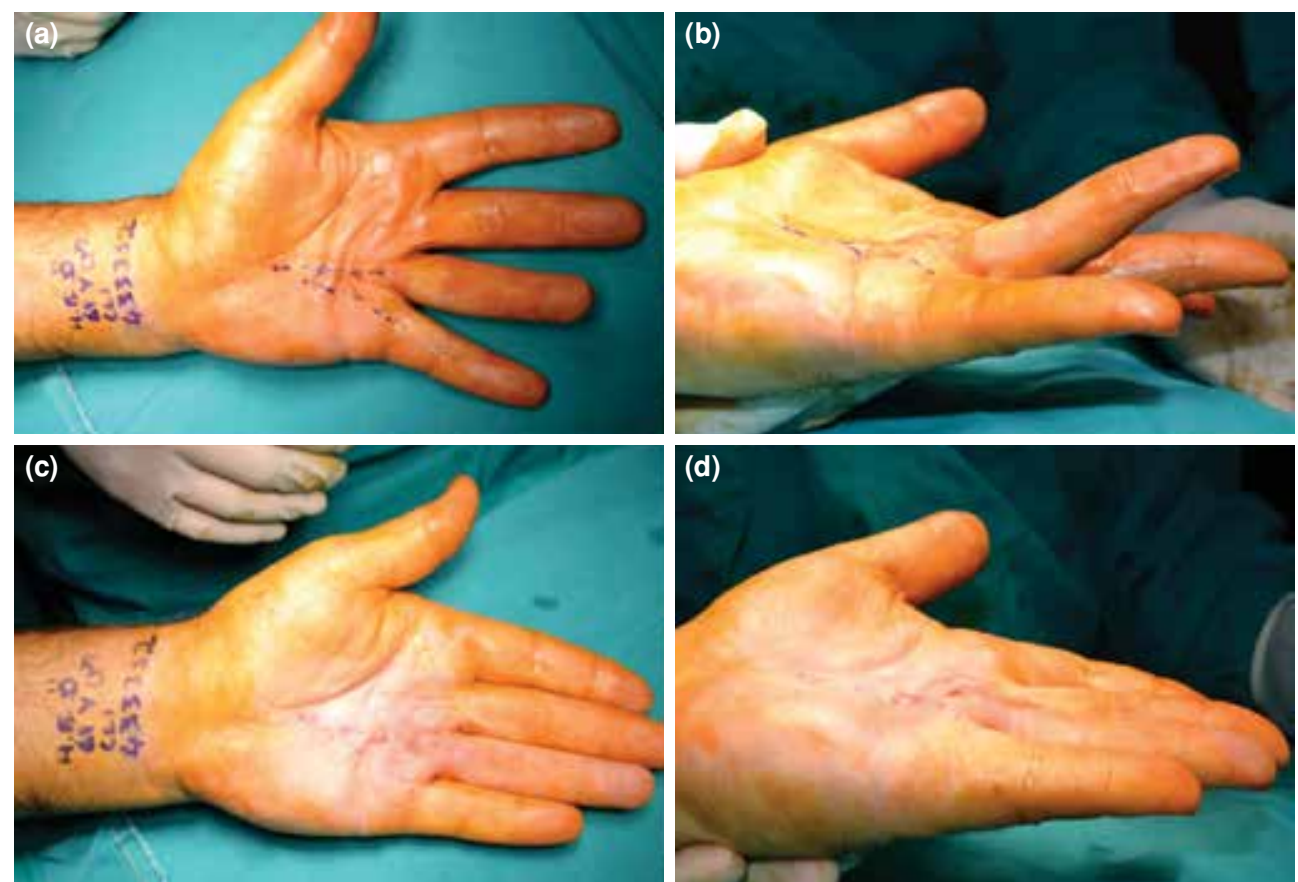

Figure 1. (a, b) Preprocedure photographs of a 61-year-old male patient's hand with Dupuytren's contracture affecting ring and little finger. Area of maximum bowstringing is the best location for percutaneous needle aponeurotomy portals. (c, d) Photographs of hand after needle aponeurotomy: ring and little fingers released. Successful treatment with needle aponeurotomy.

light gauze touch remains, the nerve is considered live even if the patient reports a subjective change, and PNA may be continued. ${ }^{[7,18]}$ We used three basic moves: clear, perforate, and sweep. Once the needle was through the dermis, the needle was oriented tangentially and a plane between dermis and cord was developed (cleared) transversely at the level of the portal at the least as wide as palpable cord width. The needle was reoriented vertically, bevel transverse, and a light reciprocating (perforating) motion was used to define the extent and surface geometry of the cord. Once the cord geometry was defined, the needle tip bevel was used to repeatedly sweep or graze the surface of the cord. While the fingers were kept in the extension posture, we performed multiple punctures with the needle that perpendicular to the cord on the different portals that were spaced $5 \mathrm{~mm}$ apart while the fingers were kept in extension posture. We changed the needles at frequent intervals to maintain the sharpness of the needle. Following the procedure, the fingers were forced to undergo hyperextension so that the remaining ligaments of the cord were broken (Figure 1). After completing the aponeurotomy procedure, we applied a light bandage with cotton and gauze wrap to the hands and allowed removal of the bandage that next day. The patients were discharged on the same day without any restriction regarding hand or finger movements. Polyclinic examinations were performed at the second, sixth weeks, third, sixth months, and first year postoperatively. Hematoma, ecchymosis, edema, infection, skin laceration, vascular/nerve/tendon injury, and pulley ruptures were reported as early complications. Prolonged edema, chronic nerve damage, finger loss/amputation, joint stiffness, flexion limitation, additional finger deformity, and reflex sympathetic dystrophy (RSD) were questioned as late complications.

\section{Statistical analysis}

The PASW version 17.0 software for Windows (SPSS Inc., Chicago, IL, USA) was used for statistical evaluation of research data. Definition of quantitative data was presented with median (minimum-maximum) and mean. The definition of qualitative data was presented as number (n) and percentage (\%). The characteristics of patient groups and the characteristics of the hands and digits were analyzed with cross tables. Categoric data were analyzed with the chi-square test. If cells contained a number less than five, we used the Fisher exact test. The rest of the data were analyzed using the Student 
t-test. Because the data from the questionnaire were too skewed to use a t-test, we used a Mann-Whitney $\mathrm{U}$ test for analysis. Significance was set at a $p$ value of less than 0.05 .

\section{RESULTS}

There were 28 patients with 75 fingers treated; $71.4 \%$ $(n=20)$ of patients were males and $28.6 \%(n=8)$ were females. Patients were followed-up for a period of 12 to 60 months with an average follow-up of 29 months. The median time between onset and operation was 4.7 years (range, 1 to 30 years). According to patients' professions, there were three categorizations as office workers $(n=9)$, heavy workers $(n=11)$, and housewives $(n=8)$. Of the patients, $92.9 \%(n=26)$ were using their right hand as a dominant hand and $7.1 \%(\mathrm{n}=2)$ were using their left hand as a dominant hand (Table I). The number of patients with only right-hand involvement was seven (25\%), number of those with only left hand involvement was six $(21.4 \%)$, and number of those with bilateral involvement was 15 (53.6\%). The affected fingers sorted by frequency were as follows: ring finger $(n=35)$, little finger $(n=19)$, middle finger $(\mathrm{n}=18)$, index finger $(\mathrm{n}=2)$, and thumb $(\mathrm{n}=1)$ (Figure 2$)$. According to the clinical grading system, 25\% ( $\mathrm{n}=7)$ of the preoperative patients were in grade 1, 64.3\% $(\mathrm{n}=18)$ were in grade 2 , and $10.7 \%(\mathrm{n}=3)$ were in grade 3 . Positive family history was stated by four patients (14.3\%). Dupuytren's contracture was present in fathers of three patients and in sister of one patient. There was recurrence in one (25\%) of these four patients. Ectopic lesions were demonstrated in four patients
(14.3\%). All of these patients had Ledderhose disease, while none had Peyronie's disease. Of the patients, $78.6 \%(\mathrm{n}=22)$ had additional diseases with DC. Eight of these patients $(28.6 \%)$ had diabetes, eight $(28.6 \%)$ had hypertension, six $(21.4 \%)$ had coronary artery disease, two $(7.1 \%)$ had chronic liver disease, and two $(7.1 \%)$ had congestive heart failure. Patients with DC who one of patient had rheumatoid arthritis, one of patient had epilepsy, one of patient had hyperlipidemia, one of patient had asthma, one of patient has goiter $(3.6 \%)$. Of the patients, $39.3 \%(\mathrm{n}=11)$ were smoking. Two of these patients $(7.1 \%)$ were both smoking and consuming alcohol. Prior to the surgery, two patients were injected steroid and two patients received physical therapy.

When the postoperative satisfaction questionnaire was performed during the followup period, $92.9 \% \quad(n=26)$ of the patients were satisfied while $7.1 \%(n=2)$ were not satisfied. In the questionnaire of reoperations, $82.1 \%(n=23)$ of the patients accepted the reoperation while $17.9 \%$ of the patients $(n=5)$ refused (Table I). After the oneyear follow-up period, recurrence was detected in 10 patients $(35.7 \%)$. The average duration of recurrence was 17.2 months (range, 2 to 48 months). Recurrence was detected in one $(12.5 \%)$ of the eight female patients whereas it was detected in 11 of the 20 male patients $(45 \%)$. The relationship between acceptance of reoperation and the time to recurrence was evaluated. In patients who accepted reoperation, the median duration

TABLE I

Demographic characteristics and results of patients treated with percutaneous needle aponeurotomy in our study

\begin{tabular}{|c|c|c|c|c|c|c|c|c|c|c|}
\hline & \multicolumn{2}{|c|}{ Gender } & \multicolumn{2}{|c|}{ Profession } & \multicolumn{2}{|c|}{$\begin{array}{l}\text { Dominant } \\
\text { hand }\end{array}$} & \multicolumn{2}{|c|}{$\begin{array}{c}\text { Patient } \\
\text { satisfaction }\end{array}$} & \multicolumn{2}{|c|}{$\begin{array}{c}\text { Reoperational } \\
\text { request }\end{array}$} \\
\hline & $\mathrm{n}$ & $\%$ & $\mathrm{n}$ & $\%$ & $\mathrm{n}$ & $\%$ & $\mathrm{n}$ & $\%$ & $\mathrm{n}$ & $\%$ \\
\hline Male & 20 & 71.4 & & & & & & & & \\
\hline Female & 8 & 28.6 & & & & & & & & \\
\hline Office worker & & & 9 & 32.1 & & & & & & \\
\hline Heavy worker & & & 11 & 39.3 & & & & & & \\
\hline House wife & & & 8 & 28.6 & & & & & & \\
\hline Right & & & & & 26 & 92.9 & & & & \\
\hline Left & & & & & 2 & 7.1 & & & & \\
\hline Satisfied & & & & & & & 26 & 92.9 & & \\
\hline Not satisfied & & & & & & & 2 & 7.1 & & \\
\hline Yes & & & & & & & & & 23 & 82.1 \\
\hline No & & & & & & & & & 5 & 17.9 \\
\hline
\end{tabular}




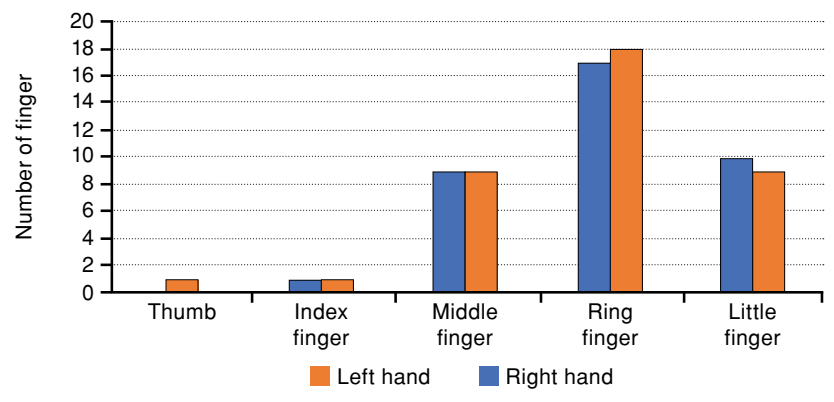

Figure 2. Distribution of involved hands and fingers of patients treated with percutaneous needle aponeurotomy in our study.

of recurrence was 15.7 months, and in patients who did not accept reoperation, recurrence it was three months $(p \geq 0.05)$. The relationship between acceptance of reoperation and the duration until operation was evaluated. In patients who accepted reoperation, the median duration until operation was 5.2 years (range, 1 to 30 years), and in patients who did not accept reoperation, it was 2.6 years (range, 1 to 4 years) ( $\mathrm{p} \geq 0.05)$. Relationship between patient satisfaction and the duration until operation time was evaluated. In patients who were satisfied, the median duration until operation time was 6.5 years (range, 1 to 30 years), while in patients who were not satisfied, it was two years (range, 1 to 4 years). Significant difference was found between patient satisfaction and the duration until operation time $(p=0.022)$. An evaluation of the relationship between recurrence and the comorbidities revealed no significant difference. Satisfaction in patients with diabetes was different from other comorbidities; all patients with diabetes were satisfied $(p=0.044)$. The relationship between acceptance of reoperation and involved hand and fingers was evaluated. When patients with both right hand and left hand with little finger involvement were compared to those without little finger involvement, there was more request for reoperation in the first group $(p \leq 0.05)$. Patients with single hand involvement and patients with both hand involvement were compared in terms of reoperation request. All patients with single hand involvement and $66.7 \%$ of patients with both hand involvement had reoperation request $(p \leq 0.05)$. Four out of five patients who refused reoperation cited additional diseases including diabetes, heart failure, and liver failure, etc. as the cause. Postoperative median DASH score was calculated as 6.5 (range, 0 to 95), while average VAS score was 0.5 (range, 0-10). Complication rate was $39.3 \%$ in 11 patients. A superficial infection developed in one patient that recovered by short-term oral antibiotic use. Seven of the nine patients who underwent skin tears during PNA application were treated with simple primary suture. In two patients, full thickness skin graft was needed for closure of the wounds. One of our patients who described hypoesthesia in ulnar digital nerve dermatome was managed without any surgical intervention. None of our patients had vascular or tendon injury, pulley rupture, prolonged edema, finger loss/amputation, additional finger deformity or RSD.

A comparison of reoperational requests between male and female patients showed that more males (78.3\%) accepted reoperation than females $(21.7 \%)$, with no statistically significant difference. Two of five patients $(40 \%)$ whose onset of disease was before the age of 50 had recurrence, whereas eight of 23 patients $(34.8 \%)$ whose onset of disease was after the age of 50 had recurrence. In $50 \%$ of patients who developed recurrence, at least one grade regression was seen according to the grade before surgery. In three patients, recurrence was in the same phase as the preoperative grade, while in two patients, recurrence developed at a later grade than the preoperative stage.

\section{DISCUSSION}

There is no radical treatment for DC and achieving perfection is not necessary, particularly when treating a disease that has a significant recurrence rate. Patients appreciate improved function and increased range of motion, even without achieving full extension. ${ }^{[1]}$ Reported recurrence rates vary from 0 to $73 \%$ for $\mathrm{PF}_{,}^{[12,19,20]} 50$ to $85 \%$ for PNF, ${ }^{[1,14,19,21]}$ and 8 to $47 \%$ for dermofasciectomy. ${ }^{[11,22]}$ The reasons these figures vary so largely are the lack of standard definitions for recurrence and the varying follow-up periods.

In recent years, the percutaneous technique has become our primary mode of surgical treatment of DC. There are few papers that have been published evaluating the results of PNA. The results of DC cases treated with PNA technique are variable (Table II). In a study conducted by Badois et al. ${ }^{[14]}$ in 1993, 90 patients treated with PNA were reported to have $50 \%$ recurrence while $20 \%$ developed early minor complication after five years of follow-up. There was no major complication in this study. Foucher et al. ${ }^{[12]}$ indicated that they achieved a recurrence rate of $58 \%$ after 3.2 years of follow-up in their PNA series. In 2006, Van Rijssen and Werker ${ }^{[21]}$ reported a recurrence rate of $65 \%$ in the follow-up of 52 patients (74 fingers) treated with PNA. Moreover, in 2012, Pess et al. ${ }^{[7]}$ stated a recurrence rate of $48 \%$ 
TABLE II

Rates of recurrence and complication with percutaneous needle aponeurotomy and fasciectomy methods in published studies

\begin{tabular}{|c|c|c|c|c|c|c|c|c|}
\hline \multirow{2}{*}{$\begin{array}{l}\text { Percutaneous needle } \\
\text { aponeurotomy }\end{array}$} & \multirow{2}{*}{$\begin{array}{l}\text { Author } \\
\text { Badois et al. }{ }^{[14]}\end{array}$} & \multicolumn{2}{|c|}{ Patients } & \multirow{2}{*}{$\begin{array}{c}\begin{array}{c}\text { Recurrence } \\
\text { rate }(\%)\end{array} \\
50\end{array}$} & \multicolumn{2}{|c|}{$\begin{array}{c}\text { Average } \\
\text { follow-up time }\end{array}$} & \multirow{2}{*}{$\begin{array}{c}\text { Complication } \\
20 \% \\
\text { (Early minor) }\end{array}$} & \multirow{2}{*}{$\begin{array}{c}\text { Yea } \\
1993\end{array}$} \\
\hline & & 90 & Patients & & 5 & Years & & \\
\hline & Foucher et al..$^{[12]}$ & 100 & Patients & 58 & 3.2 & Years & 1 major complication & 2003 \\
\hline & Van Rijssen and Werker ${ }^{[21]}$ & $\begin{array}{l}52 \\
74\end{array}$ & $\begin{array}{l}\text { Patients } \\
\text { Fingers }\end{array}$ & 65 & 33 & Months & Not stated & 2006 \\
\hline & Pess et al. ${ }^{[7]}$ & $\begin{array}{r}474 \\
1,013\end{array}$ & $\begin{array}{l}\text { Patients } \\
\text { Fingers }\end{array}$ & 48 & 3 & Years & $\begin{array}{c}3.4 \% \\
\text { (Apart from skin complications) }\end{array}$ & 2012 \\
\hline & Nydick et al. ${ }^{[24]}$ & 30 & Patients & 0 & 6 & Months & $0 \%$ & 2013 \\
\hline & Herrera et al.. ${ }^{[15]}$ & $\begin{array}{l}193 \\
525\end{array}$ & $\begin{array}{l}\text { Hands } \\
\text { Fingers }\end{array}$ & 12 & 4.5 & Months & 7 patients (Major) & 2015 \\
\hline & Zhou et al. ${ }^{[23]}$ & 78 & Patients & Not stated & 12 & Weeks & $5.2 \%$ & 2016 \\
\hline & Our study & $\begin{array}{l}28 \\
75\end{array}$ & $\begin{array}{l}\text { Patients } \\
\text { Fingers }\end{array}$ & 35.7 & 29 & Months & $\begin{array}{l}39.3 \% \\
\text { (Minor) }\end{array}$ & 2017 \\
\hline \multicolumn{9}{|l|}{ Fasciectomy } \\
\hline & Cools and Verstreken ${ }^{[27]}$ & 33 & Hands & 33.5 & 2.5 & Years & $21 \%$ & 1994 \\
\hline & Armstrong et al. ${ }^{[11]}$ & $\begin{array}{l}103 \\
143\end{array}$ & $\begin{array}{l}\text { Patients } \\
\text { Fingers }\end{array}$ & 8.4 & 5.8 & Years & Not stated & 2000 \\
\hline & Dias and Braybrooke ${ }^{[28]}$ & $\begin{array}{l}1,177 \\
1,871\end{array}$ & $\begin{array}{l}\text { Patients } \\
\text { Fingers }\end{array}$ & 15 & 27 & Months & $46 \%$ & 2006 \\
\hline & Özkaya et al. ${ }^{[29]}$ & 42 & Patients & 0 & 5 & Years & $16.6 \%$ & 2010 \\
\hline & Çiloğlu and Duran ${ }^{[30]}$ & 56 & Patients & 8.3 & No & stated & $8.3 \%$ & 2013 \\
\hline & Zhou et al. ${ }^{[23]}$ & 103 & Patients & Not stated & 12 & Weeks & $24.3 \%$ & 2016 \\
\hline
\end{tabular}

in 474 treated patients (1,013 fingers) and followedup by a mean follow-up duration of three years.

Furthermore, Herrera et al. ${ }^{[15]}$ reported a recurrence rate of $12 \%$ in the early results of 193 hands and 525 fingers treated with PNA with an average follow-up duration of 4.5 months in 2015. In addition, major complications developed in seven patients. Zhou et al. ${ }^{[23]}$ compared patients with similar characteristics treated with PNA and PF concurrently. At the end of the 12-week follow-up, complications were demonstrated in $5.2 \%$ of patients treated with PNA and $24.3 \%$ of patients treated with PF. On the other hand, Herrera et al. ${ }^{[15]}$ suggested that the low recurrence rate in their study was due to the different surgical technique by using a larger bore needle and aggressive release of fibrotic skin. Since the average duration of recurrence in our study was 17.2 months, we may note that the common feature of studies with low recurrence rates is that they have short-term follow-up. ${ }^{[15,24]}$ The recurrence rates in two studies of the same author, of which the follow-up periods were 5.0 and 4.4 years, were reported to be $85 \%$ and $50 \%$, respectively. ${ }^{[19,25]}$ Our results compare favorably with the existing literature. In our study, the recurrence rate $(35.7 \%)$ is similar with the literature $(12-65 \%)$.
Moreover, regarding the complication rates, there is no significant difference between PNA and related publications (Table II). We noted skin tears in nine of the 28 patients. Although this is not higher than the prior literature suggesting skin tears in one third of patients after PNA, ${ }^{[18]}$ it has increased the rate of complications in our study. We observed only one nerve injury that resulted in hypoesthesia; we can avoid most nerve injuries by good anatomical knowledge and the use of precise indications and rigorous techniques. ${ }^{[12]}$ Patience is necessary and the temptation to use a needle larger than 25G should be resisted. In our study, we used a $26 \mathrm{G}$ needle as a scalpel for aponeurotomy. It is critical to ask patients if they feel an electric shock each time the needle is inserted in a portal. Pinching the cord between the fingertips allows precise placement of the needle. ${ }^{[7]}$

Corticosteroid injections have been previously advocated as a treatment for patients with early Dupuytren's disease or painful nodules. Injection of a corticosteroid into palmar nodules has shown to result in nodule softening and pain reduction. Previous studies suggest that both PNA and corticosteroid injections result in contracture correction and combining these two treatment options might yield 
more favorable outcomes than either option alone. A study showed that combining the molecular effects of the corticosteroid with the mechanical effects of PNA resulted in a significantly higher degree of correction than PNA alone, despite during a short-term follow-up period. ${ }^{[26]}$ Therefore, after release, portals and nodules may be injected with depot corticosteroid such as triamcinolone acetate or its equivalent. After release, we did not inject corticosteroid because our aim in this study was to evaluate the outcomes of the DC cases treated with percutaneous aponeurotomy technique.

Several risk factors have been suggested that adversely influence the interval to and severity of recurrence. These include onset of the disease before the age 50 years, familial predisposition, presence of ectopic lesions, bilateral disease, radial involvement, and involvement of the little finger. Our findings do not correlate with the findings of many authors, ${ }^{[13,14]}$ which support the view that Dupuytren's disease is a risk factor for recurrence. We were unable to find a statistically significant influence on recurrence of early onset, familial predisposition, ectopic lesions, smoking and alcohol consumption, gender, comorbidities such as diabetes, epilepsy, hypertension, coronary artery disease, chronic liver disease, or congestive heart failure.

Nydick et al. ${ }^{[24]}$ in their study comparing collagenase injection with PNA in 30 patients, although one patient received a second collagenase injection for continued ring finger PIP joint contracture, they reported no recurrence in the early period results after six months of follow-up. There was also no significant difference between patients treated with collagenase and PNA in this study. Side effects are common after collagenase injection and occur in $>95 \%$ of patients. These include pain, swelling, ecchymosis, blistering, bleeding, pruritus, lymphadenopathy, erythema, and streaking. ${ }^{[24]}$ Cost and insurance coverage may be a factor in choosing one treatment over the other. If one treatment fails, the other can then be utilized.

A literature review for reports of fasciectomy indicates that recurrence rates are lower than those treated with PNA technique. On the other hand, the complication rates are rather higher than those treated with the PNA in cases treated with fasciectomy. Cools and Verstreken ${ }^{[27]}$ reported the results of 33 patients treated by combining $\mathrm{PF}$ with the open palm technique after a mean follow-up of 2.5 years and demonstrated $33.5 \%$ recurrence and $21 \%$ complication rates (apart from RSD). In Armstrong et al.'s[1] report published in 2000, 103 patients had a recurrence rate of $8.4 \%$ after an average follow-up of 5.8 years on 143 fingers. Dias and Braybrooke $^{[28]}$ showed a recurrence rate of $15 \%$ after a mean follow-up of 27 months in a large series of 1,871 fingers, while the postoperative complication rate was $46 \%$. In 2010, Özkaya et al. ${ }^{[29]}$ published the results of their study on 42 patients treated with PF. In this study, no recurrence developed in any patient while at the end of a mean follow-up period of five years (range, 1 to 10 years) at least one major complication developed in $16.6 \%$ of the patients. In a similar study, Çiloğlu and Duran ${ }^{[30]}$ reported that in 56 patients treated with PF technique, $8.3 \%$ had recurrence while $8.3 \%$ had complications. According to the results we obtained in our study, we may state that our recurrence rate $(35.7 \%)$ is higher than the recurrence rate of patients treated by fasciectomy method (8.3-33.5\%). However, a comparison of the results with the complications rates in fasciectomy technique shows that the rates are similar (Table II). In a randomized controlled study comparing the outcomes of PNA and limited fasciectomy after five years, Van Rijssen ${ }^{[19]}$ reported a five-year recurrence rate of $85 \%$. However, patients who recurred still preferred PNA over fasciectomy for repeat treatment. A study by Van Rijssen et al. ${ }^{[31]}$ comparing the direct outcomes of PNF and limited fasciectomy for Dupuytren's disease demonstrated that the mean DASH score for PNA was 9 while the mean DASH score for limited fasciectomy was 16 . In our study, postoperative median DASH score was calculated as $6.5(0-95)$, while average VAS score was $0.5(0-10)$.

Dupuytren's contracture is a common disease that may be diagnosed by simple clinical physical examination. Besides, it has an important place in the practice of hand surgery. PNA technique provides significant advantages in the choice of surgical treatment options for DC as it is less invasive than other methods, feasible under local anesthesia, has low complication rates with shorter hospital stay, allows rapid return to work, and has low cost. PNA has been criticized due to high rates of recurrence relative to open fasciectomy procedures. However, the implications of recurrence following PNA may be different than that following open release. The majority of patients with recurrent disease after PNA may be treated safely and effectively with a repeat PNA procedure. ${ }^{[15-25]}$

Limitations in this study include the absence of preoperative DASH and VAS scores and the small sample size. Furthermore, initial corrections achieved post procedure were not compared with corrections maintained at the first follow-up visit. 
In conclusion, a near-complete correction of deformities and the high satisfaction rate $(92.9 \%)$ of the postoperative patients in our study as well as the $82.1 \%$ rate of reoperation request indicate that PNA is an effective method for the treatment of primary Dupuytren's disease. Additionally, PNA allows both hands to be treated on consecutive days and is safe in high-risk patients.

\section{Declaration of conflicting interests}

The authors declared no conflicts of interest with respect to the authorship and/or publication of this article.

\section{Funding}

The authors received no financial support for the research and/or authorship of this article.

\section{REFERENCES}

1. Bayat A, McGrouther DA. Management of Dupuytren's disease--clear advice for an elusive condition. Ann R Coll Surg Engl 2006;88:3-8.

2. Larocerie-Salgado J, Davidson J. Nonoperative treatment of PIPJ flexion contractures associated with Dupuytren's disease. J Hand Surg Eur Vol 2012;37:722-7.

3. Betz N, Ott OJ, Adamietz B, Sauer R, Fietkau R, Keilholz L. Radiotherapy in early-stage Dupuytren's contracture. Longterm results after 13 years. Strahlenther Onkol 2010;186:8290.

4. Ketchum LD. The Rationale for treating the nodule in Dupuytren's disease. Plast Reconstr Surg Glob Open 2015;2:278.

5. Jemec B, Linge C, Grobbelaar AO, Smith PJ, Sanders R, McGrouther DA. The effect of 5-fluorouracil on Dupuytren fibroblast proliferation and differentiation. Chir Main 2000;19:15-22.

6. Kuhn MA, Wang X, Payne WG, Ko F, Robson MC. Tamoxifen decreases fibroblast function and downregulates TGF(beta2) in dupuytren's affected palmar fascia. J Surg Res 2002;103:146-52.

7. Pess GM, Pess RM, Pess RA. Results of needle aponeurotomy for Dupuytren contracture in over 1,000 fingers. J Hand Surg Am 2012;37:651-6.

8. Stewart CJ, Davidson DM, Hooper G. Re-operation after open fasciotomy for Dupuytren's disease in a series of 1,077 consecutive operations. J Hand Surg Eur Vol 2014;39:553-4.

9. Gelman S, Schlenker R, Bachoura A, Jacoby SM, Lipman J, Shin EK, et al. Minimally invasive partial fasciectomy for Dupuytren's contractures. Hand (N Y) 2012;7:364-9.

10. Lubahn JD, Lister GD, Wolfe T. Fasciectomy and Dupuytren's disease: a comparison between the open-palm technique and wound closure. J Hand Surg Am 1984;9:53-8.

11. Armstrong JR, Hurren JS, Logan AM. Dermofasciectomy in the management of Dupuytren's disease. J Bone Joint Surg Br 2000;82:90-4.

12. Foucher G, Medina J, Navarro R. Percutaneous needle aponeurotomy: complications and results. J Hand Surg $\mathrm{Br}$ 2003;28:427-31.
13. Srinivasan RC, Shah AS, Jebson PJ. New treatment options for Dupuytren's surgery: collagenase and percutaneous aponeurotomy. J Hand Surg Am 2010;35:1362-4.

14. Badois FJ, Lermusiaux JL, Massé C, Kuntz D. Non-surgical treatment of Dupuytren disease using needle fasciotomy. Rev Rhum Ed Fr 1993;60:808-13.

15. Herrera FA, Mitchell S, Elzik M, Roostaeian J, Benhaim P4. Modified percutaneous needle aponeurotomy for the treatment of dupuytren's contracture: early results and complications. Hand (N Y) 2015;10:433-7.

16. Atik OS. Which articles do we prefer to publish? Eklem Hastalik Cerrahisi 2018;29:1.

17. Trojian TH, Chu SM. Dupuytren's disease: diagnosis and treatment. Am Fam Physician 2007;76:86-9.

18. Eaton C. Percutaneous fasciotomy for Dupuytren's contracture. J Hand Surg Am 2011;36:910-5.

19. van Rijssen $A L$, ter Linden $H$, Werker PM. Five-year results of a randomized clinical trial on treatment in Dupuytren's disease: percutaneous needle fasciotomy versus limited fasciectomy. Plast Reconstr Surg 2012;129:469-77.

20. Jurisić D, Ković I, Lulić I, Stanec Z, Kapović M, Uravić M. Dupuytren's disease characteristics in Primorsko-goranska County, Croatia. Coll Antropol 2008;32:1209-13.

21. van Rijssen AL, Werker PM. Percutaneous needle fasciotomy in dupuytren's disease. J Hand Surg Br 2006;31:498-501.

22. Kelly C, Varian J. Dermofasciectomy: a long term review. Ann Chir Main Memb Super 1992;11:381-2.

23. Zhou C, Selles RW, Slijper HP, Feitz R, van Kooij Y, Moojen $\mathrm{TM}$, et al. Comparative effectiveness of percutaneous needle aponeurotomy and limited fasciectomy for Dupuytren's contracture: A multicenter observational study. Plast Reconstr Surg 2016;138:837-46.

24. Nydick JA, Olliff BW, Garcia MJ, Hess AV, Stone JD. A comparison of percutaneous needle fasciotomy and collagenase injection for dupuytren disease. J Hand Surg Am 2013;38:2377-80.

25. van Rijssen AL, Werker PM. Percutaneous needle fasciotomy for recurrent Dupuytren disease. J Hand Surg Am 2012;37:1820-3.

26. McMillan C, Binhammer P. Steroid injection and needle aponeurotomy for Dupuytren disease: long-term followup of a randomized controlled trial. J Hand Surg Am 2014;39:1942-7.

27. Cools H, Verstreken J. The open palm technique in the treatment of Dupuytren's disease. Acta Orthop Belg 1994;60:413-20.

28. Dias JJ, Braybrooke J. Dupuytren's contracture: an audit of the outcomes of surgery. J Hand Surg Br 2006;31:514-21.

29. Özkaya Ö, Yeşilada AK, Karşıdağ S, Soydan AT, Uğurlu K, Baş L. Dupuytren's contracture: Etiology, diagnosis and surgical treatment, retrospective analysis of ten years. Türkiye Klinikleri J Med Sci 2010;30:553-8.

30. Çiloğlu SN, Duran A. A retrospective assessment of 56 Dupuytren's contracture patients with partial fasciectomy. Turkish Journal of Plastic Surgery 2013;21:27-30.

31. van Rijssen AL, Gerbrandy FS, Ter Linden H, Klip H, Werker PM. A comparison of the direct outcomes of percutaneous needle fasciotomy and limited fasciectomy for Dupuytren's disease: a 6-week follow-up study. J Hand Surg Am 2006;31:717-25. 